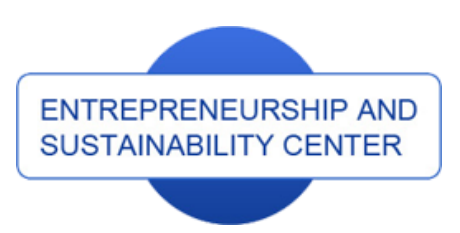

Publisher

http://jssidoi.org/esc/home

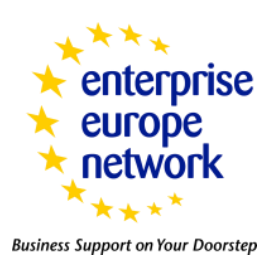

CASPA

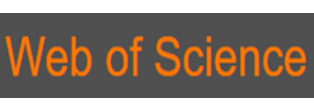

1) Clarivate

\title{
LIFELONG LEARNING AS AN EMPLOYEE RETENTION TOOL. COMPARATIVE BANKING ANALYSIS*
}

\author{
Jerzy Kaźmierczyk ${ }^{1}$, Gulnara Fatykhovna Romashkina ${ }^{2}$, Przemysław Macholak ${ }^{3}$ \\ ${ }^{1}$ Poznań University of Economics and Business, Al. Niepodległości 10, 61-875 Poznań, Poland \\ ${ }^{2}$ Tyumen State University, Ulitsa Volodarskogo, 6, Tyumen, Tyumen Oblast, Russia \\ ${ }^{3}$ University of Pennsylvania, Philadelphia, PA 19104, USA
}

E-mails: ${ }^{1}$ jerzy.kazmierczyk@ue.poznan.pl ; ${ }^{2}$ g.f.romashkina@utmn.ru $;{ }^{3}$ Przemyslaw.Macholak.wh19@wharton.upenn.edu

Received 15 February 2020; accepted 30 June 2020; published 30 September 2020

\begin{abstract}
Different companies choose different training strategies to reinforce human capital. The main aim of this paper is to measure the impact of training on the loyalty of bank employees. Various factors that could potentially impact the loyalty levels were considered. This comparative quantitative study is the first one that investigates the differences in loyalty levels that was carried out on a sample of Polish and Russian bank employees. The study manages to elaborate on the results of an original comprehensive survey conducted in both Poland and Russia on a sample of more than 2000 bank employees. Kolmogorov-Smirnov test, Mann-Whitney test, Kruskal-Wallis test, exploratory factor analysis, Cronbach's alpha, Kaiser-Mayer-Olkin and Bartlett's test and answer tree (CHAID method) were used. The paper confirms breaking up general loyalty concept into affective commitment and calculative loyalty. Training does not impact employees' rational choices. However, employers can strengthen loyalty by using instruments influencing employees' emotionality and thus strengthen human capital.
\end{abstract}

Keywords: lifelong learning; employee retention tool; training, human capital; e-learning

Reference to this paper should be made as follows: Kaźmierczyk, J., Romashkina, G.F., Macholak, P. 2020. Lifelong learning as an employee retention tool. Comparative banking analysis. Entrepreneurship and Sustainability Issues, 8(1), 1064-1080. http://doi.org/10.9770/jesi.2020.8.1(71)

JEL Classifications: J00, J39, G21

Additional disciplines (besides field of economics reflected in JEL classifications): management; sociology; psychology

\footnotetext{
* This research was supported by the project, which has received funding from the Implemented with support of the Russian Foundation for Basic Research (project 19-29-07131 "Modelling and measurement of human capital and its forms in the context of economy digitalization: resources, flows, institutions")
} 


\section{ENTREPRENEURSHIP AND SUSTAINABILITY ISSUES}

ISSN 2345-0282 (online) http://jssidoi.org/jesi/

2020 Volume 8 Number 1 (September)

http://doi.org/10.9770/jesi.2020.8.1(71)

\section{Introduction}

Data confirm that among adults (25 to 64 years old) Russians are more educated than Poles (55\% vs. $30 \%$ of tertiary education graduates; OECD, 2017). Paradoxically, this high human capital is not reflected in modern business practice. While Russian students are characterized by significant achievements in particular tests measuring skills, those extra-ordinary results are less and less impressive as the education process continues, i.e. the closer it is to obtaining Master's degree (Silova, Millei \& Piattoeva, 2017). Meanwhile, modern businesses require flexibility and critical thinking on the highest level - by universities or employers through various training initiatives.

In Poland, on the other hand, the number of university students increased fivefold from the 1990s till 2005/2006 and then started falling (Ministerstwo Nauki i Szkolnictwa Wyższego, 2013). Not only there is significantly more young Poles with higher education degree than it used to be in the past, but they also strongly strive for applying their knowledge in a job setting (Wach-Kąkolewicz \& Sławecki, 2012). The learning paradigm has been undergoing significant changes. As a society, we are moving from education for life to life-long learning. Those with lower acquisition costs and higher efficiency enjoy comparative advantages. And education is crucial in achieving both of them.

The labour market results from the interplay of two main actors - employers and employees. The dynamic changes it has been undergoing over the recent years and the influence of the government have been reflected in rich literature (Apella \& Zunino, 2017; Du \& Yang, 2014; Antoszak, 2016; Olafsdottir et al., 2015; Paszkowicz \& Garbat, 2013; Greve, 2017; Andrianova \& Tarasova, 2017; Kogay E.A. et al., 2008; Kalinowska-Sufinowicz, 2013; Jaźwiński, 2017; Jędrzejczak-Gas \& Wyrwa, 2005; Parreira do Amaral \& Zelinka, 2019; Roumell Erichsen, \& Salajan, 2014; Wieczorek-Szymańska, 2017). On the one hand, many available publications focus on downsizing and restructuring in the financial services across the whole world. On the other hand, employers often complain about the high level of rotation and job mobility, or about situations when they train employees first and then the same employees leave for the competitors. Similar processes are generally universal across the globe, and they occur in Poland and Russia as well.

Moreover, employees' hierarchy of values has also become more dynamic. In the times when most experts predict on average 6 different career paths undertaken by current graduates, loyalty is not taken for granted any more (Association of Accounting Technicians report, 2015). As Lurie and Frenkel report, personal development and happiness take the top spot not only in terms of professional growth but also in other areas of life, as the evidence ranging from the popularity of extreme sports to new types of family relationships suggests (2002).

Achieving a competitive advantage depends to a large extent on people employed in the organization: their competencies, knowledge and personality traits. At the same time, shortage of specialists (talents) can be observed. Organizations undertake coordinated actions aimed at retaining valuable employees. In this context, the attention of researchers focuses on issues related to the attachment of employees to the organization. Many researchers devote attention to affective attachment, because numerous studies have proved that it plays the most important role: brings the most benefits in shaping relations between employees and positively correlates with the level of work performance and profits (Lewicka, 2013; Czarnovsky, 2008; Soojung \& Jeongkoo, 2018; Fryzel \& Seppala, 2016; Ying et al., 2016). In modern organizations, human capital is key, and employee loyalty is part of this trend.

Among various branches of the global economy where one can observe the importance of loyalty-related issues, the banking sector is a particularly interesting one. Perceived as the main cause of the Great Recession, the whole industry implemented restructuring programs, that led to changes in the level and structure of employment 


\section{ENTREPRENEURSHIP AND SUSTAINABILITY ISSUES}

ISSN 2345-0282 (online) http://jssidoi.org/jesi/

2020 Volume 8 Number 1 (September)

http://doi.org/10.9770/jesi.2020.8.1(71)

(Baszyński, 2016; Pająk, Kamińska, \& Kvilinskyi, 2016). Moreover, it should be noted that crisis was a prime example of negative consequences of profit-seeking at any cost. Such behaviours did not strengthen loyalty.

In the changing environment of the never-ending restructuring and downsizing processes in the banking sector, the issue of employee's loyalty has become crucial to maintaining a high level of services offered. Academia also accepts this claim; as stated by Narteh and Odoom: loyalty is very important in service-based industries like the banking sector, when the relationships with customers are important (2015).

To analyze the issue Polish and Russian bankers were chosen as a subject of the research. A strong trend to maximize workers' productivity is currently observable in both countries. In Poland, Western management methods are present, introduced by foreign capital that took over most of the industry in the 90's and early 2000's. Moreover, a recent tendency to renationalize, or 'repolonize' banks also impacts the workers. Russian banking system, on the other hand, is dominated by national capital. This trend has been strengthened as a result of EU and American sanctions against Russia. Centralization of particular banking functions such as HR, accounting, IT, compliance, etc., has also been present in Poland since the last few years. Over the past few years: we can observe constantly growing number of banks that have lost their licenses in Russia. 2014 - 86 banks, 2015 - 93, 2016 - 97 banks, 2017 - 40 banks, 2018 - 66 banks (The situation in the banking sector in December and the forecast for 2017; Banking license 2018; Banking license 2017). Both Polish and Russian banks aim at introducing Western management toolkits (Kaźmierczyk \& Żelichowska, 2017), such as management style and organizational culture.

The main aim of this paper is to measure the impact of training on the loyalty of bank employees. There are few precise methods of measuring the level of loyalty in the literature. The available tools are based on expressing opinions on the behaviour of organizations generally represented by most employees. It must be stressed that loyalty is not measured frequently in organizations.

The following theses are propounded in this paper:

H1: Employees who took part in training programs are more loyal than the ones who did not.

$\mathrm{H} 2$ : Employees who took part in the online training programs are less loyal than the ones who took part in traditional training.

To accomplish the research aims the authors used source literature in English, Polish and Russian on economics, sociology, human resources management, banking and industrial and organizational psychology (EBSCO, The ACM Digital Library, BazEkon, Emerald, ProQuest). There is a limited presence of quantitative research in the field of lifelong learning (Boeren, 2018). An additional original survey of 1,920 bank employees in Poland and 359 bank employees in Russia was conducted to bridge this gap.

Following the introduction, this paper includes formulation of the theses. Then the research sample and the method adopted are described. Finally, the research results and conclusions are presented.

\section{Loyalty: hypotheses to be tested}

H1: Employees who took part in training programs are more loyal than the ones who did not.

Training impacts loyalty of employers through a few mechanisms simultaneously. Because of its signaling function (Spence, 1973), employees feel that employers care about them when they are sent to attend training initiatives (higher safety due to the smaller probability of being sacked - in that case the training cost would become a sunk cost). They are moreover grateful to their employers for investing in them, which equals to moving a company's surplus (cost of a training initiative) into an employee's development. Additionally, different forms of training usually support interactions between employees, coaches, and employers (Andrzejczak, 2010). 


\section{ENTREPRENEURSHIP AND SUSTAINABILITY ISSUES}

ISSN 2345-0282 (online) http://jssidoi.org/jesi/ 2020 Volume 8 Number 1 (September) http://doi.org/10.9770/jesi.2020.8.1(71)

Such interactions lead to strengthening bonds between these actors, as a result of potentially supporting loyalty. This hypothesis can be thus be the best summarized in a sentence that people trained by their company will exhibit higher levels of their loyalty. In their study, Narteh and Odoom (2015) indeed confirmed that training contributes to employee loyalty in the banking sector. $62 \%$ of their sample had a higher education degree, which makes the structure of surveyed similar to this study, for this proportion in Polish and Russian banks equals to around 70-80\% (Kaźmierczyk 2011, pp. 115-124).

H2: Employees who took part in the online training programs are less loyal than the ones who took part in traditional training.

While e-learning may mean achieving cost or time efficiencies (George, 2002; Schmeeckle, 2003; Andrzejczak, 2010) it does not necessarily lead to the better results in terms of loyalty. In his study Schmeeckle (2003) reports that 'The classroom group felt more motivated and positive toward their instruction than the online group' and while online training negatives were countered by 'convenience and time efficiency', the trainees still claimed that 'the biggest disadvantage of online training was missing classroom interaction' - a crucial factor in forming loyalty towards the company. The loyalty from a broader sense is a complex set of mutually intertwined relationships, affections to different coworkers, values, objects, together with conflicts between them, rather than an abstract organization being the only one subject of loyalty (see Schrag, 2001 for example). Therefore, traditional training methods with more co-workers interaction prove better suited to form a stronger sense of loyalty towards co-workers and the employer at the end.

To sum up, it can be stated that the workers who were involved in e-learning initiatives are less loyal than the ones under traditional training. Those taking part in the conventional programs simultaneously with training are somehow interacting with other workers, thus strengthening relationships between them. Loyalty as such exists in relation to someone (co-workers, superiors), it can be seen as an intertwined network of connections between all of them, not in relation to an organization as such. Therefore, learning, repeating and implementing new skills together during the training sessions, as well as integration time, also in more informal settings, offer an unbeatable advantage of traditional training methods over e-learning one in terms of their impact on loyalty.

\section{Methodology}

In order to measure loyalty level in banks, a questionnaire was used which covered various aspects of loyalty (items on a 0-4 scale). Following Allen and Meyer (1990) classic study it was assumed that loyalty can be divided up into calculative loyalty and affective commitment. The exploratory factor analysis (EFA) was performed to confirm this assumption and to confirm the quality of the calculated loyalty indices for Poland and Russia together and for both countries separately (principal component analysis, PCA, oblimin). The total variance explained was $68.06 \%$ for both countries together, $66.74 \%$ for Russia and $67.68 \%$ for Poland respectively. All the data used in the exploratory factor analysis yielded two components with high correlations. This was confirmed by a scree plot, which also pointed to two components (both in Poland and Russia). Table 1 presents the matrix of components for Poland and Russia. The reliability of the scale of loyalty measured by Cronbach's alpha was respectively for both countries together/for Russia/for Poland: 0.707/0.712/0.686, for the affective commitment it was: $0.826 / 0.808 / 0.820$, and for calculative loyalty: $0.677 / 0.656 / 0.681$. 


\section{ENTREPRENEURSHIP AND SUSTAINABILITY ISSUES}

ISSN 2345-0282 (online) http://jssidoi.org/jesi/ 2020 Volume 8 Number 1 (September) http://doi.org/10.9770/jesi.2020.8.1(71)

Table 1. The component matrix of the general index of loyalty and its subindices (exploratory factor analysis) for Poland and Russia

\begin{tabular}{|c|c|c|c|c|c|c|}
\hline \multirow[b]{2}{*}{ Statements } & \multicolumn{2}{|c|}{$\mathrm{PL}+\mathrm{RU}$} & \multicolumn{2}{|c|}{ PL } & \multicolumn{2}{|c|}{ RU } \\
\hline & 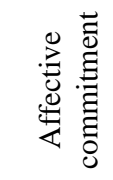 & 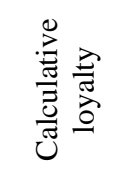 & 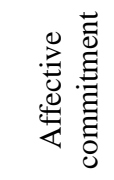 & 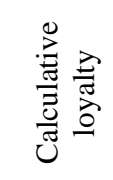 & 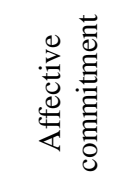 & 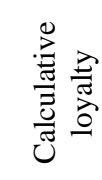 \\
\hline In general, I am satisfied with my work in the Bank & 0.885 & & 0.880 & & 0.885 & \\
\hline $\begin{array}{l}\text { I am ready to recommend employment in my Bank to relatives or } \\
\text { friends }\end{array}$ & 0.873 & & 0.874 & & 0.835 & \\
\hline I am proud of my work and I admit it openly & 0.828 & & 0.820 & & 0.845 & \\
\hline $\begin{array}{l}\text { Work is just work. A person should always seek better conditions } \\
\text { of employment for himself (a reversed scale applied) }\end{array}$ & & 0.793 & & 0.789 & & 0.770 \\
\hline $\begin{array}{l}\text { At present, the employer should not expect the employee to be } \\
\text { loyal solely to him (a reversed scale applied) }\end{array}$ & & 0.778 & & 0.793 & & 0.764 \\
\hline $\begin{array}{l}\text { In times of crisis, the employee reserves the right to seek a new, } \\
\text { safer job (a reversed scale applied) }\end{array}$ & & 0.773 & & 0.766 & & 0.788 \\
\hline
\end{tabular}

Source: Author's own computations based on the survey data

Notice: Kaiser-Mayer-Olkin and Bartlett`s test: $\mathrm{p}=0.000$ (for both countries together, for Poland, for Russia). Due to the unsatisfying results of the factor analysis the authors dropped the following items: I refrain from criticizing the Bank when I am dissatisfied with its activities (item loading=0.270); The employee should be guided by a career and manage it skillfully (a reversed scale applied) (item loading=0.367). Both decreased the value of calculated indices and did not significantly the quality of indices received as a result of factor analysis.

The research agenda was designed to inquire about various types of training: online, on the job (OJT), outside your workplace, training conducted exclusively for one bank's employees, training organised for one bank's employees and employees of other organizations, and no training. Next, an analysis was conducted to check for differences in loyalty and its' affective and calculative commitments given the differing type of training.

The research results presented are part of a broader study. Thus, the description of the research method and data is applicable also to the results of research on other aspects of HRM and other papers by the authors. You can find more detailed data in our previous papers (Davydenko et al., 2018; Kaźmierczyk, 2019; Kaźmierczyk \& Chinalska, 2018; Kaźmierczyk et al., 2019; Kaźmierczyk et al., 2020; Kaźmierczyk \& Żelichowska, 2017).

\section{Data}

The data from the survey, which was conducted in Poland between January 2016 and April 2016 and in Russia (the Tyumen region) between February 2017 and April 2017, were used to test the research thesis. In Poland, more than 20,000 requests, and in Russia more than 4,000 queries were sent asking recipients to fill in the questionnaire via e-mail, social networking websites (such as Facebook, GoldenLine and LinkedIn) and thematic forums. Both electronic versions (Anonymous study of bank employees, 2016) and physical copies of the questionnaire were used in the survey.

The main survey was preceded by a two-stage pilot survey in Poland. Firstly, the survey was conducted on a small group of participants (180 students in Poland). In the second stage of the pilot study, the target group consisted of 100 employees from the banking sector in Poland. The aim was to reveal any inconsistencies and to examine 


\section{ENTREPRENEURSHIP AND SUSTAINABILITY ISSUES}

ISSN 2345-0282 (online) http://jssidoi.org/jesi/

2020 Volume 8 Number 1 (September)

http://doi.org/10.9770/jesi.2020.8.1(71)

whether the questions were understandable. Thanks to the pilot study, the questionnaire was modified and improved. Then, the survey was translated into Russian by a group of 12 philologists, psychologists, bankers and HRM specialists. The two-stage study in Russia was conducted on a group of 50 students and then a group of 50 bankers.

The composition of the research sample according to gender, the type of education and the type of bank corresponds to the structure of employment in the banking sector in Poland (Anonymous, pp. 115-124). The mean age of the respondents was 36.6 years in Poland and 31.7 in Russia. The mean work experience in banking was 7.8 years in Russia and 12.1 in Poland. The mean total work experience of the respondents was 15.0 years in Poland and 11.2 in Russia.

\section{Loyalty: empirical research}

H1: Employees who took part in training programs are more loyal than the ones who did not.

Several pairs of bankers were separated: trained in a certain way and not trained in a given way, and then their level of loyalty, affective commitment and calculative loyalty were compared. Because the normal distribution could not be assumed, the Mann-Whitney test was conducted. The first pair includes those trained in any way and those who have not been trained at all.

Based on types of training they participated in, employee's scores of general loyalty, affective commitment and calculative loyalty were compared. Between employees that participated in any training initiative and those, who did not at all, the following results were obtained. H1 was partly confirmed in respect to affective commitment in Poland and Russia and to loyalty in Poland. Trained employees in Poland and Russia tend to be more loyal emotionally than the not trained ones (Table 2, Table 4). The difference in affective commitment between the trained (3.03 in Russia, 2.49 in Poland) and the untrained (2.76 in Russia, 2.18 in Poland) banking employees was significant yet minimal (Glass rank coefficient around 0.20), similarly in case of loyalty in Poland. Participation in training did not impact calculative loyalty in both analyzed countries and loyalty in Russia.

Additionally, a similar comparison was conducted among employees trained under non-bank specific initiatives and those not trained under this type of training (Table 2, Table 5). Trained Polish bankers exhibited higher loyalty levels (1.79 vs. 1. 60), higher calculative loyalty (0.91 vs. 0.78$)$ and higher affective commitment (2.67 vs. 2.43). The magnitude of the differences was relatively low (Glass rank coefficient between 0.11-0.17). No significant difference was observed in Russia, what can most likely be attributed to the small sample size.

Moreover, the groups of employees who took part in a company-specific training were also compared to those who did not (Table 2, Table 6). No statistically significant differences were observed between them. Only in case of general loyalty (1.68 vs. 1.56) and affective commitment (2.54 vs. 2.36$)$ among Polish employees, a small difference in favour of the trained ones was observed (Glass rank coefficient up to 0.1).

Participating in OJT did not impact loyalty in Russia (Table 2, Table 7). The only statistically significant difference was observed in calculative loyalty among Polish employees (0.75 vs. 0.83) (Glass rank coefficient=0.07). Interestingly enough, participating in OJT instead of increasing calculative loyalty level, decreased it.

E-learning training was associated with a higher affective commitment among both Russian (3.03 vs. 2.64), as well as Polish employees (2.44 vs. 2.29) (Glass rank coefficient=0.27, Table 2, 8). Russian employees also exhibited a significant difference in general loyalty level (2.11 vs. 1.78). 


\section{ENTREPRENEURSHIP AND SUSTAINABILITY ISSUES}

ISSN 2345-0282 (online) http://jssidoi.org/jesi/ 2020 Volume 8 Number 1 (September) http://doi.org/10.9770/jesi.2020.8.1(71)

To sum up, in Russia participating in training essentially did not matter for loyalty level of employees. Lack of statistically significant differences may be a result of a small sample. In Poland, the most meaningful for loyalty level training were traditional not bank-specific training programs. Participating in them statistically increased each of analyzed types of loyalty. Internal bank-specific training increased loyalty and affective commitment. Interestingly enough among Polish employees participating in OJT training negatively correlated with calculative loyalty level. This particular type of training does not seem to matter to individual employees. The authors suppose this finding may be attributed to the fact that usually the youngest and newest employees participate in this type of training and they exhibit the lowest values of loyalty. This claim requires a further in-depth research because the obtained data doesn't allow to confirm or negative this assumption.

Table 2. Average values of loyalty, calculative loyalty and affective commitment depending on the type of training and country

\begin{tabular}{|c|c|c|c|c|c|c|c|c|c|c|}
\hline & \multicolumn{2}{|c|}{$\begin{array}{l}\text { Any type of } \\
\text { training }\end{array}$} & \multicolumn{2}{|c|}{$\begin{array}{l}\text { Non-bank specific training opened to } \\
\text { employees from different companies }\end{array}$} & \multicolumn{2}{|c|}{$\begin{array}{l}\text { Internal, bank- } \\
\text { specific training }\end{array}$} & \multicolumn{2}{|l|}{ OJT } & \multicolumn{2}{|c|}{ Elearning } \\
\hline & Yes & No & Yes & No & Yes & No & Yes & No & Yes & No \\
\hline Loyalty in Russia & 2.11 & 1.89 & 2.10 & 2.09 & 2.11 & 2.06 & 2.08 & 2.09 & 2.11 & 1.78 \\
\hline Calculative loyalty in Russia & 1.17 & 0.97 & 1.13 & 1.15 & 1.15 & 1.14 & 1.14 & 1.16 & 1.17 & 0.88 \\
\hline $\begin{array}{l}\text { Affective commitment in } \\
\text { Russia }\end{array}$ & 3.03 & 2.76 & 3.09 & 2.99 & 3.04 & 2.97 & 3.01 & 2.99 & 3.03 & 2.64 \\
\hline Loyalty in Poland & 1.64 & 1.50 & 1.79 & 1.60 & 1.68 & 1.56 & 1.62 & 1.64 & 1.61 & 1.57 \\
\hline Calculative loyalty in Poland & 0.80 & 0.81 & 0.91 & 0.78 & 0.82 & 0.76 & 0.75 & 0.83 & 0.77 & 0.85 \\
\hline $\begin{array}{l}\text { Affective commitment in } \\
\text { Poland }\end{array}$ & 2.49 & 2.18 & 2.67 & 2.43 & 2.54 & 2.36 & 2.49 & 2.45 & 2.44 & 2.29 \\
\hline
\end{tabular}

Note: The indices do not follow normal distribution (Kolmogorov-Smirnov test's results are summarized below): loyalty in both countries together (arithmetic mean $=1.70$, standard deviation $=0.67$, test statistics $=0.072$, asymptotic significance (two-tailed) $=0.000$ ); calculative loyalty in both countries together (mean $=0.85$, standard deviation $=0.80$, test statistics $=0.166, p$ (two-tailed) $=0.000$ ), affective commitment in both countries together (mean $=2.55$, standard deviation $=0.92$, test statistics $=0.140, \mathrm{p}$ (two-tailed) $=0.000$ ); total loyalty in Russia (mean $=2.10$, standard deviation $=0.69$, test statistics $=0.053$, p (two-tailed) $=0.016$ ); calculative loyalty in Russia (mean $=1.15$, standard deviation $=0.85$, test statistics $=0.154$, $\mathrm{p}$ (two-tailed $)=0.000$ ); affective commitment in Russia (mean=3.01, standard deviation $=0.86$, test statistics $=0.148, \mathrm{p}$ (two-tailed) $=0.000)$; total loyalty in Poland (mean=1.63, standard deviation=0.64, test statistics $=0.081$, $\mathrm{p}$ (twotailed) $=0.000$ ); calculative loyalty in Poland (mean $=0.80$, standard deviation $=0.77$, test statistics $=0.170, \mathrm{p}$ (two-tailed) $=0.000)$; affective commitment in Poland (mean=2.47, standard deviation $=0.91$, test statistics $=0.142$, $\mathrm{p}$ (two-tailed) $=0.000$ ).

Source: Author's own computations based on the survey data

H2: Employees who took part in the online training programs are less loyal than the ones who took part in traditional training.

Based on the data survey three groups of employees were analyzed: those, who participated exclusively in elearning, those who participated in any other type of traditional training (i.e. OJT, internal specific and not bankspecific training) and those, who participated in both traditional and non-traditional initiatives. Due to the nonnormality traits of distribution, Kruskal-Wallis test was performed. Conducted test showed that no statistically significant difference between loyalty, affective commitment, and calculative loyalty among employees who were trained by e-learning, those trained in a conventional way, and those trained through both methods was observed (Table 3). 
Table 3. Average values of loyalty, calculative loyalty and affective commitment depending on conventionality of the training type and

\begin{tabular}{|l|l|l|l|l|l|l|}
\hline & $\begin{array}{l}\text { Traditional } \\
\text { training only }\end{array}$ & $\begin{array}{l}\text { E-learning } \\
\text { only }\end{array}$ & $\begin{array}{l}\text { Both traditional and e-learning } \\
\text { training initiatives }\end{array}$ & $\begin{array}{l}\text { Test } \\
\text { statistic }\end{array}$ & $\begin{array}{l}\text { Significance } \\
\text { two-tailed }\end{array}$ \\
\hline Loyalty in Russia & 2.05 & 2.09 & 2.10 & 0.076 & 2 & 0.963 \\
\hline Calculative loyalty in Russia & 1.05 & 1.13 & 1.17 & 0.702 & 2 & 0.704 \\
\hline Affective commitment in Russia & 3.00 & 3.05 & 3.01 & 0.528 & 2 & 0.768 \\
\hline Loyalty in Poland & 1.72 & 1.52 & 1.62 & 3.587 & 2 & 0.166 \\
\hline Calculative loyalty in Poland & 0.91 & 0.77 & 0.77 & 1.831 & 2 & 0.400 \\
\hline Affective commitment in Poland & 2.54 & 2.25 & 2.47 & 5.663 & 2 & 0.059 \\
\hline
\end{tabular}

Source: Author's own computations based on the survey data

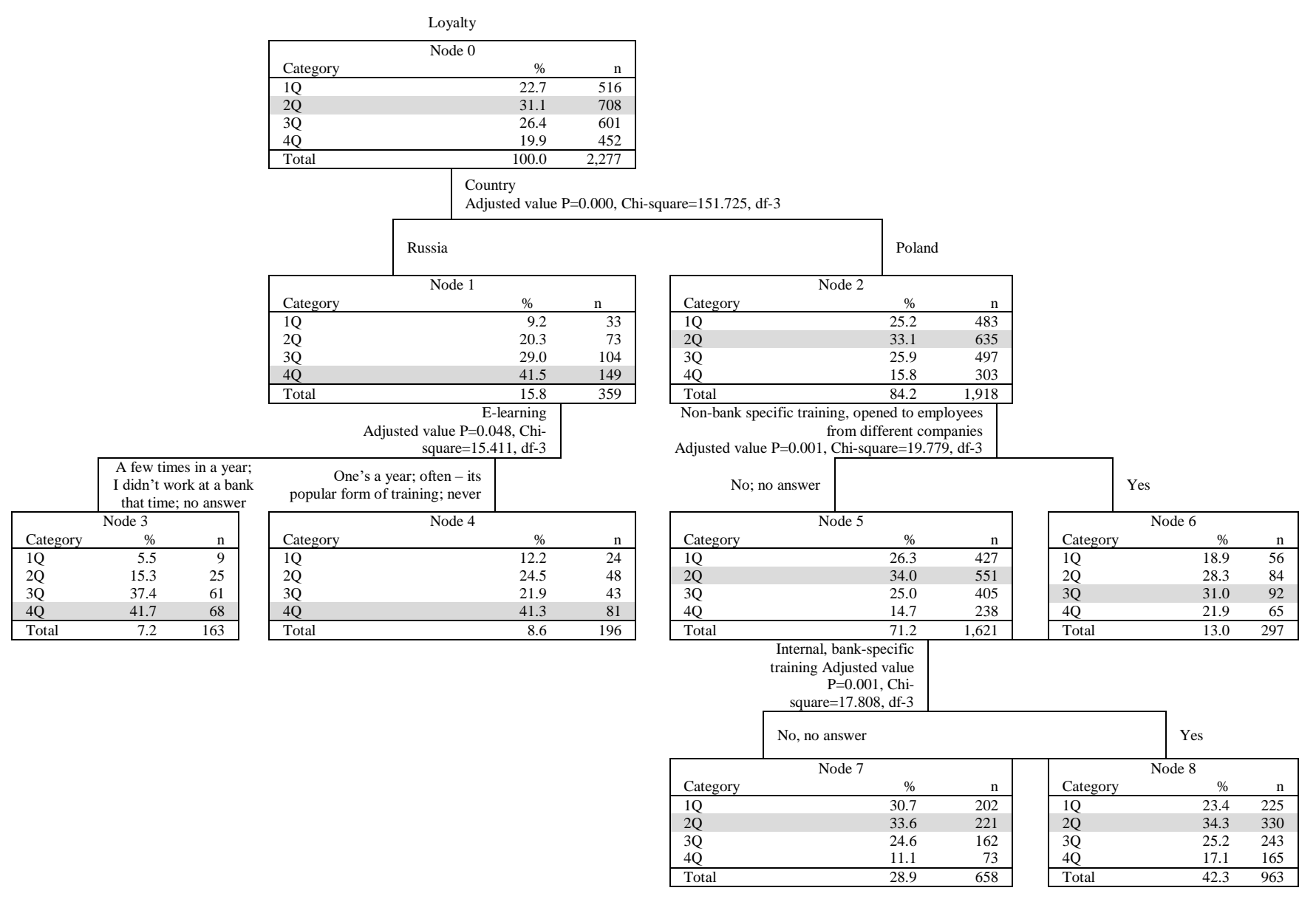

Figure 1. Loyalty index answer tree (CHAID method).

Source: Author's own computations based on the survey data. 


\section{ENTREPRENEURSHIP AND SUSTAINABILITY ISSUES}

ISSN 2345-0282 (online) http://jssidoi.org/jesi/ 2020 Volume 8 Number 1 (September) http://doi.org/10.9770/jesi.2020.8.1(71)

Since statistic tests have different values for subgroups, we also presented these relationships in the form of a decision tree. We defined the loyalty, calculative loyalty and affective commitment indices from the interval resulting from quartile borders (respectively: 1.33/1.67/2.17; 0.33/0.67/1.33, 2.0/2.67/3.0). According to the decision tree analysis (Figure 1-3), the most important factor determining varying levels of loyalty, calculative loyalty and affective commitment, was the country in which the data was collected. In Poland the group with highest levels of loyalty (15.8\%), calculative loyalty $(24.5 \%)$ and affective commitment (19.1\%) was relatively smaller than in Russia (respectively 41.5\%; 41.6\%; 45.7\%), and the group with lowest loyalty (25.2\%), calculative loyalty $(23.6 \%)$ and affective commitment levels $(30.4 \%)$ in Poland was respectively much larger than in Russia $(9.2 \%, 12.3 \%, 15.0 \%)$. These differences were statistically significant and sometimes amounted to as much as doubling the percentage size of the group.

Level of loyalty in Poland was the most impacted by participation in non-bank specific training (Figure 1). It pushed the distribution to the right, and increased the size of the most loyal employees (from 14.7\% to $21.9 \%$ ) and decreased the number of the ones with the lowest loyalty level (from 26.3\% to 18.9\%). On the other hand, Polish employees, who did not participate in neither non-bank specific training nor internal, bank-specific training exhibited lower loyalty levels than those, who participated in at least the latter ones. Thus, for loyalty in Poland the traditional, open, non-bank specific training and traditional internal bank-specific training initiatives are the most important. In case of Russia, the main differentiator was participation in the e-learning courses. The most beneficial to the loyalty level was sporadic participation in such training, i.e. few times a year. The Bell curve or the reverse U-shape relation between e-learning and loyalty levels can be connected to employees' perception of such training. Potentially, if they take place too often, employees become weary or overtired what leads to a decrease in loyalty level. Similarly the employees participating in e-learning less than once a year were characterized by low loyalty levels. Perhaps they feel unappreciated. Therefore, we suggest that an optimal level of learning initiatives exists, and after crossing this point, increased participation in learning leads to lower loyalty.

To summarize, the biggest share of employees characterized by the lowest loyalty consisted of Polish employees that did not participate in neither non-bank specific training nor internal bank-specific training (30.7\%). In contrast, the biggest share of employees characterized by the highest loyalty consisted of Russian banks' employees $(41.7 \%)$ who took part in e-learning training few times.

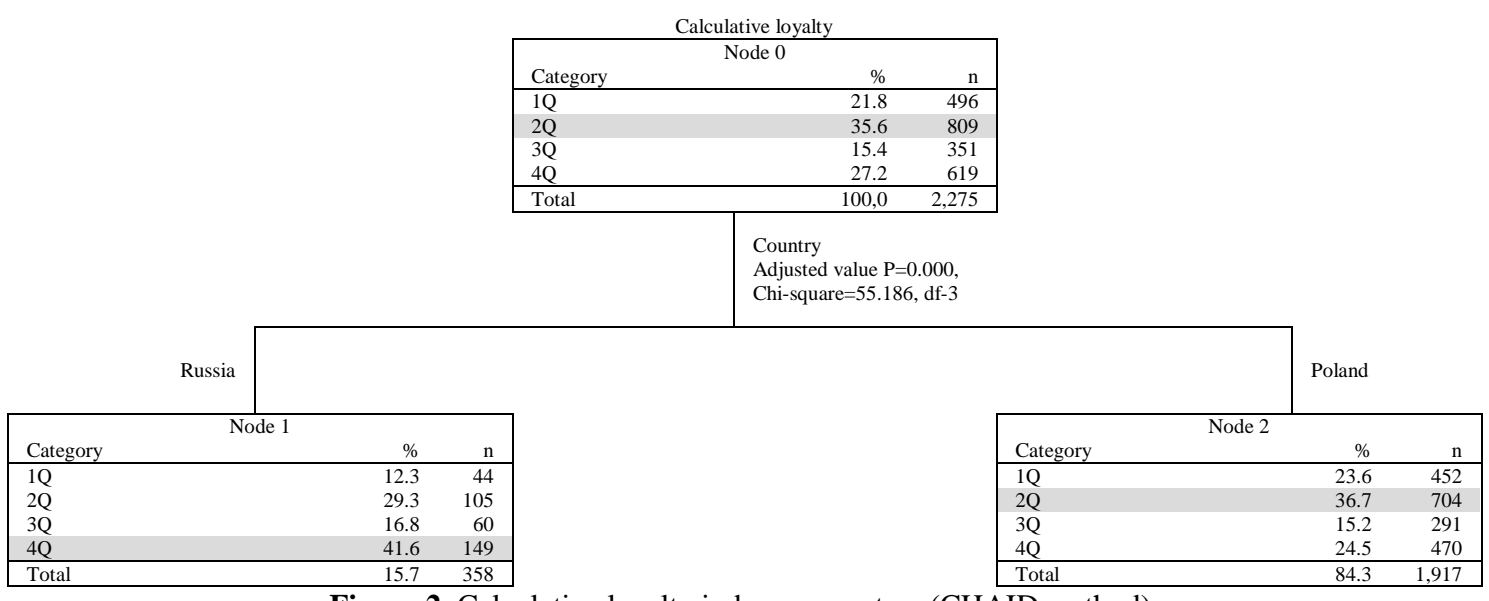

Figure 2. Calculative loyalty index answer tree (CHAID method).

Source: Author's own computations based on the survey data. 
Calculative loyalty did not depend on participation in training (Figure 2). It hold true for both Poland and Russia. It could be hence suspected that employees' rational calculation is a basis for assessing their situation on the labour market. Perhaps due to the extent to what their job involves risk valuation and estimated value of different investments, bank employees approach their job market prospects from a similar perspective. If the market provides them with rationale for that, they are willing to change their employer. Similarly, lack of stability, lack of possibility to change the current employer for a better one and access to information may make them more loyal to the current employer. Loyalty seems to be only a natural extension of career management.

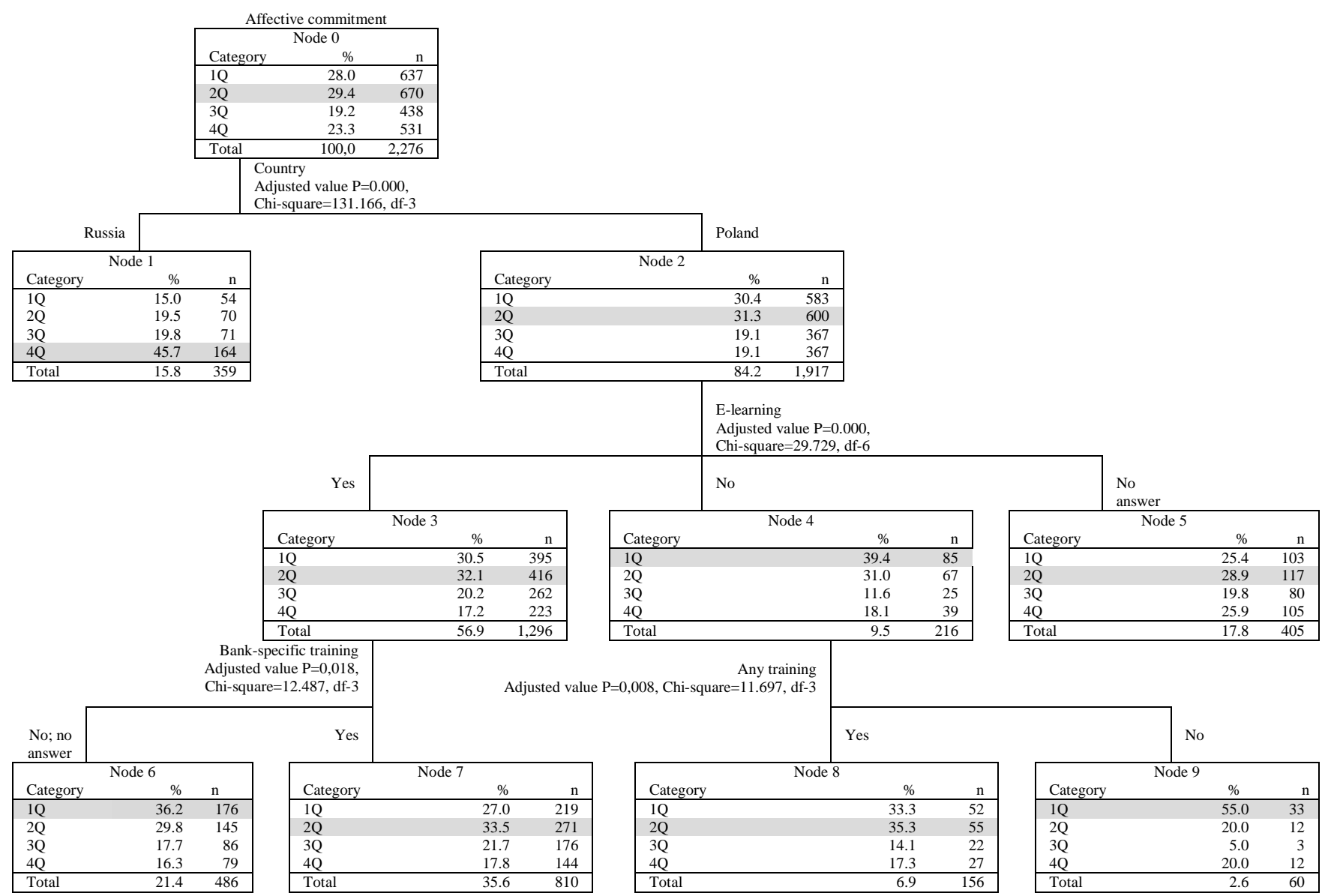

Figure 3. Affective commitment index answer tree (CHAID method).

Source: Author's own computations based on the survey data.

Affective commitment in Russia was not dependent on participation in training (Figure 3). In Poland e-learning participation slightly increased affective commitment. Furthermore affective commitment in Poland depended on first, participating in internal, bank-specific training and second, participating in any type of training. The first one decreased the share of disloyal employees (from $36.2 \%$ to $27.0 \%$ ). No training participation whatsoever led to a significant reduction in loyalty levels, i.e. increasing the share of the least loyal employees (from $33.3 \%$ to $55.0 \%$ ). To sum up, the biggest group that exhibited the lowest affective commitment levels were not-trained Polish employees (55.0\%). The biggest group that exhibited the highest affective commitment were Russian employees $(45.7 \%)$. 


\section{ENTREPRENEURSHIP AND SUSTAINABILITY ISSUES}

ISSN 2345-0282 (online) http://jssidoi.org/jesi/

2020 Volume 8 Number 1 (September)

http://doi.org/10.9770/jesi.2020.8.1(71)

With loyalty being beyond control of employer, an aspect that can be influenced by them is emotions and satisfaction with work (Kaźmierczyk \& Wyrwa, 2017). However, it should be noted that even the highest levels of happiness with a team and tasks performed may not protect the employer from losing their employees. It could be assessed that loyalty shares similar characteristics to motivation according to the Herzberg's theory (Herzberg et al., 2011) theory. Job stability and career management can be seen as hygiene factors, and any real increase in loyalty can be shaped by an employer in the affective commitment area.

\section{Conclusions}

Poland and Russia were analyzed intentionally. They are both post-socialist countries that after fall of the socialism and the Soviet Union chose completely separate development paths. However, they are still relatively homogenous and similar societies belonging to the Slavic cultural sphere. A differentiating factor between the two is individualism. Russia represents a more traditional culture with values leaning towards a collective approach. The next question to be asked is which aspect of culture belongs to the global context and which has a national character. A stronger market-orientation among Poles is observed and perhaps this is why it is easier to adopt Western organizational norms and labour market values there than in Russia. That being said the Russian employees are also afraid of their future because of the undergoing structural changes in the banking system.

With high turnover and recruitment costs, retention through loyalty may appear to be a more cost-effective alternative. However, impact of loyalty is complex and apart from obvious benefits, it can also lead to negative consequences. One of them is limited mobility. While there could be two opposite effects, in general intuition suggests that employees will strengthen their commitment to employers after the latter ones invest in the human capital of the former.

This paper considered various factors that could potentially impact the loyalty levels. Among them intuitively the following were the most important: country of origin, age, participation in any type of training, participation in non-bank specific training, participation in internal (bank-specific) training, participation in on the job training, and participation in e-learning. The main factor correlating with loyalty level was country of origin. Despite outlined similarities among Polish and Russian economies and cultures, it turns out that the level of loyalty in banks in Russia differs significantly and is higher than in Poland. Polish labour market shows convergence to western markets where employees look for better options on the market. In bad economic conditions, job insecurity is an important channel strengthening loyalty. Moreover, there is a possibility that Russian employees feel pressure to report higher loyalty. In Poland participation in traditional forms of training is statistically significant for the loyalty level. The authors suppose that such traditional forms of training create an environment beneficial to strengthening relationships between employees. A potential criticism of findings could be based upon the geographical concentration of the Russian results, however, other studies show similar differences between Poland and Russia.

The uniqueness of the article is based on applying two research methods to testing suggested hypotheses. Both of them provided converging results. Loyalty comparison is an important field that could potentially inform research concerning lifelong learning. This comparative study is the first one that investigates the differences in loyalty levels that was carried out on a sample of Polish and Russian bank employees and took into account the influence of training. Loyalty as a complex construct constitutes an interesting research field, especially for those who deal with the problem of relational orientation in management.

In conclusion, it should be underlined that especially for customer-facing services loyalty among employees needs further scrutiny. Banks should naturally constitute an important part of this growing field, especially given the issue of trust in their functioning on a macro and micro level, as represented by banking secrecy and morally 


\section{ENTREPRENEURSHIP AND SUSTAINABILITY ISSUES}

ISSN 2345-0282 (online) http://jssidoi.org/jesi/ 2020 Volume 8 Number 1 (September) http://doi.org/10.9770/jesi.2020.8.1(71)

objectionable management practices that ultimately led to the Great Recession. Despite banks' natural tendency to guard their sensitive information, the study manages to elaborate on the results of an original large survey conducted in both Poland and Russia.

The novelty of the paper could be summarized in the fact that it confirms reasoning behind breaking up general loyalty concept into affective commitment and calculative loyalty. The factor analysis showed that this approach is the recommended one when analyzing big datasets. Significant differences between affective commitment and calculative loyalty were observed. Training does not impact employees' rational choices. However, employers can strengthen loyalty by using instruments influencing employees' emotionality. Calculative commitment is only moderately affected as a result of training. An aspect that could be effectively impacted by training is affective commitment. In case of Poland participation in traditional, open and non-bank specific training and in internal, bank-specific training was the most correlated with high loyalty values. On the job training and e-learning methods should be organised with caution, given that quite often they do not represent significant value for trainees and can be perceived as a dull obligation rather than an actual investment in human capital, especially when they take place too often. The problem of the subjective and objective effectiveness of various training initiatives requires further study, similarly to the loyalty and impact of training among the youngest and the leastexperienced employees.

\section{References}

Allen, N.J., \& Meyer, J.P. (1990). The measurement and antecedents of affective, continuance and normative commitment to the organization. Journal of Occupational and Organizational Psychology, 63(1), 1-18. http://dx.doi.org/10.1111/j.2044-8325.1990.tb00506.x

Andrianova, E., \& Tarasova, A. (2017). The social consequences of government intervention in labor management in Russia. Zeszyty Naukowe Polskiego Towarzystwa Ekonomicznego w Zielonej Górze [Scientific Journal of the Polish Economic Society in Zielona Góra], 7 , $5-18$.

Andrzejczak, A. (2010). Projektowanie i realizacja szkoleń [Designing and implementing trainings], Poznań: Polish Economic Publisher.

Antoszak, P. (2016). Logistycy i transportowcy na rynku pracy [Logistics and transporters on the labor market]. In M. Osińska \& I. Urbanyi-Popiołek (Eds.), Problemy logistyki i zrównoważonego rozwoju [Logistics and sustainable development problems] (pp. 109-120). Bydgoszcz: Publisher of the University of Economy in Bydgoszcz.

Apella, I., \& Zunino, G. (2017). Technological Change and the Labor Market in Argentina and Uruguay: A Task Content Analysis. Revista de Economia, 24 (2), 79-121.

Association of Accounting Technicians report from 2015. (2015). Retrieved from https://www.aat.org.uk/news/article/work-numbers (accessed 1 June 2018).

Banking license. (2018). Retrieved from https://bankogolik.com/nolicense-2018 (accessed 1 June 2018).

Banking license. (2017). Retrieved from https://bankogolik.com/nolicense-2017 (accessed 1 June 2018).

Baszyński, A. (2016). Reformy bankowe a wzrost gospodarczy. Przykład krajów transformujących się [Banking reform and economic growth. Example countries in transition]. Scientific Journal of Polish Economic Society in Zielona Góra, 4, 4-16. https://doi.org/10.26366/PTE.ZG.2016.34

Boeren, E. (2018). The Methodological Underdog: A Review of Quantitative Research in the Key Adult Education Journals. Adult Education Quarterly, 68(1), 63-79. http://dx.doi.org/10.1177/0741713617739347

Czarnovsky, M. (2008). Learning's Role in Employee Engagement: An AST, Research Study, VA: American Society Training and Development, Alexandria. 


\section{ENTREPRENEURSHIP AND SUSTAINABILITY ISSUES}

ISSN 2345-0282 (online) http://jssidoi.org/jesi/ 2020 Volume 8 Number 1 (September) http://doi.org/10.9770/jesi.2020.8.1(71)

Davydenko, V., Kaźmierczyk, J., Romashkina, G., \& Andrianova, E. (2018). A Comparative Analysis of the Levels of Collective Trust among the Banking Staff in Poland and Russia. Comparative Sociology, 17(3-4), 299-317. https://doi.org/10.1163/15691330-12341462

Du, Y., \& Yang, C. (2014). Demographic Transition and Labour Market Changes: Implications for Economic Development in China. Journal of Economic Surveys, 28(4), 617-635. http://dx.doi.org/10.1111/joes.12072

Ewin, R.E. (1993). Corporate loyalty: Its objects and its grounds. Journal of Business Ethics, 12(5), 387-396. http://dx.doi.org/10.1007/BF00882029

Finnis, J. (2011). Bernard Williams on truth's values. In J. Finnis (Ed.), Reason in action: Collected Essays (pp. 92-103). Vol. I, Oxford: Oxford University Press. http://dx.doi.org/10.1093/acprof:oso/9780199580057.003.0006

Fryzel, B., \& Seppala, N. (2016). The effect of CSR evaluations on affective attachment to CSR in different identity orientation firms. Business Ethics: A European Review, 25(3), 310-326. http://dx.doi.org/10.1111/beer.12116

George, T. (2002). All aboard e-learning at air, rail companies. Information Week, 914(26).

Greve, B. (2017). Welfare States and Labour Market Change: What is the Possible Relation? Social Policy \& Administration, 51(2), 389403. http://dx.doi.org/10.1111/spol.12293

Herzberg, F., Mausner, B., \& Snyderman, B.B. (2011). The motivation to work, Vol. 1. Transaction Publishers. http://dx.doi.org/10.4324/9781315124827

Jaźwiński, I. (2017). Kapitał ludzki w polityce regionalnej [Human capital in regional policy], Szczecin: University of Szczecin Scientific Publishing House.

Jędrzejczak-Gas, J., \& Wyrwa, J. (2005). Tworzenie nowych miejsc pracy poprzez działania wspierające i promujące rozwój przedsiębiorczości [Creation of new jobs through activities supporting and promoting the development of entrepreneurship]. In B. Pietrulewicz (Ed.), Wspótczesne problemy edukacji, pracy i zatrudnienia pracowników [Contemporary problems of education, work and employment of employees] (pp. 267-277). Zielona Góra: University of Zielona Góra.

Kalinowska-Sufinowicz, B. (2013). Popytowe i podażowe determinanty aktywizacji zawodowej osób młodych [Demand and supply determinants of professional activation of young people]. Przeglad Zachodniopomorski [West Pomeranian Review], 1(3), 93-105.

Katz, D., \& Kahn, R.L. (1978). The Social Psychology of Organizations, New York: Wiley.

Kaźmierczyk, J. (2011). Technologiczne i społeczno-ekonomiczne determinanty zatrudnienia $w$ sektorze bankowym $w$ Polsce [Technological and socio-economic determinants of employment in the banking sector in Poland]. Warsaw: CeDeWu.

Kaźmierczyk, J. (2019). Workforce segmentation model: banks' example. Entrepreneurship and Sustainability Issues, 6 (4), $1938-1954$. http://doi.org/10.9770/jesi.2019.6.4(28).

Kaźmierczyk, J., \& Chinalska, A. (2018). Flexible forms of employment, an opportunity or a curse for the modern economy? Case study: banks in Poland. Entrepreneurship and Sustainability Issues, 6(2), 782-798. http://doi.org/10.9770/jesi.2018.6.2(21)

Kaźmierczyk, J., Tarasova, A., \& Andrianova, E. (2019). Factors Affecting the Use of Outplacement in the Banking Sectors of Poland and Russia1. Management, 23(2), 263-280. http://doi.org/10.2478/manment-2019-0030

Kaźmierczyk, J., Tarasova, A., \& Andrianova, E. (2020). Outplacement - An employment safety tool but not for everyone. The relationship between job insecurity, new job opportunities and outplacement implementation. Cogent Business \& Management, 7(1), 1-15.: https://doi.org/10.1080/23311975.2020.1723210

Kaźmierczyk, J, \& Wyrwa, J. (2017). Selected Indicators of Job Satisfaction: A Comparative Analysis of Polish and Russian Banks. Tyumen State University Herald, 3(4), 19-40. https://doi.org/10.21684/2411-7897-2017-3-4-19-40

Kaźmierczyk, J. \& Żelichowska, E. (2017). Satisfaction of Polish Bank Employees with Incentive Systems: An Empirical Approach. Baltic Region, 9(3), 58-86. https://doi.org/10.5922/2079-8555-2017-3-5

Kogay, E.A., Kulseeva, T.G., Pasovec, Ju.M., \& Telegin, A.A. (2008). Sociokulturny portret Kurskoj oblasti [Sociocultural portrait of the Kursk region], Kursk: Publishing House of the Kursk State University. 


\section{ENTREPRENEURSHIP AND SUSTAINABILITY ISSUES}

ISSN 2345-0282 (online) http://jssidoi.org/jesi/ 2020 Volume 8 Number 1 (September)

http://doi.org/10.9770/jesi.2020.8.1(71)

Lewicka, D. (2013). Supporting Innovation through HRM Practices - Importance of Motivation. International Journal of Innovation and Learning, 14(2), 217-240. http://dx.doi.org/10.1504/IJIL.2013.055525

Lurie, Y., \& Frenkel, D.A. (2002). Mobility and loyalty in labour relations: An Israeli case. Business Ethics: A European Review, 11 (3), 295-301. http://dx.doi.org/10.1111/1467-8608.00287

Narteh, B., \& Odoom, R. (2015). Does Internal Marketing Influence Employee Loyalty? Evidence From the Ghanaian Banking Industry. Services Marketing Quarterly, 36(2), 112-135. http://dx.doi.org/10.1080/15332969.2015.1014237

OECD. (2017). Education at a Glance 2017: OECD Indicators, OECD Publishing, Paris. http://dx.doi.org/10.1787/eag-2017-en

Olafsdottir, T., Hrafnkelsson, B., \& Asgeirsdottir, T.L. (2015). The Icelandic Economic Collapse, Smoking, and the Role of Labor-Market Changes. European Journal of Health Economics, 16(4), 391-405.

Pająk, K., Kamińska, B., \& Kvilinskyi, O. (2016). Modern trends of financial sector development under the virtual regionalization conditions. Financial and Credit Activity: Problems of Theory and Practice, 2(21), 204-217. https://doi.org/10.18371/fcaptp.v2i21.91052

Parreira do Amaral, M., \& Zelinka, J. (2019). Lifelong learning policies shaping the life courses of young adults. An interpretative analysis of orientations, objectives and solutions. Comparative Education, 55(3), 404-421. http://dx.doi.org/10.1080/03050068.2019.1619333

Paszkowicz, M.A., \& Garbat, M. (2013). Przedmowa [Preface]. In M.A. Paszkowicz, \& M. Garbat, (Eds.), Osoby z niepetnosprawnościami w polityce społecznej [People with disabilities in social policy] (pp. 5-8). Vol. 1, Zielona Góra: Polish Economic Society Zielona Góra.

Roumell Erichsen, E., \& Salajan, F.D. (2014). A Comparative Analysis of E-Learning Policy Formulation in the European Union and the United States: Discursive Convergence and Divergence. Comparative Education Review, 58(1), 135-165.

Schmeeckle, J.M. (2003). Online training: An evaluation of the effectiveness and efficiency of training law enforcement personnel over the internet. Journal of Science Education and Technology, 12 (3), 205-260.

Schrag, B. (2001). The moral significance of employee loyalty. Business Ethics Quarterly, 11 (1), 41-66. http://dx.doi.org/10.2307/3857868

Silova, I., Millei, Z., Piattoeva, N. (2017). Interrupting the Coloniality of Knowledge Production in Comparative Education: Postsocialist and Postcolonial Dialogues after the Cold War. Comparative Education Review, 61(S1), S74-S102. http://dx.doi.org/10.1086/690458

Soojung, L., \& Jeongkoo, Y. (2018). Does The Authenticity of Corporate Social Responsibility Affect Employee Commitment? Social Behavior \& Personality: an International Journal, 46(4), 617-632.

Spence, M. (1973). Job Market Signaling. The Quarterly Journal of Economics, 87 (3), 355-274. http://dx.doi.org/10.2307/1882010

Szkolnictwo wyższe w Polsce [Higher education in Poland]. (2013). (Rep.). (n.d.). Ministerstwo Nauki i Szkolnictwo Wyższego [Ministry of Science and Higher Education].

The situation in the banking sector in December and the forecast for 2017. (2017). Retrieved from http://riarating.ru/banks/20170201/630054980.html

Wach-Kąkolewicz, A., \& Sławecki, B. (2012). "Chcemy pracy" - motywacje i oczekiwania studentów wobec uczelni ekonomicznych [We want jobs! : motivations and expectations of economic universities' students in Poland]. Edukacja Ekonomistów i Menedżerów [Education of Economists and Managers. Problems. Innovations. Projects], 3 (25), 149-165.

Wieczorek-Szymańska, A. (2017). Organizational maturity in diversity management. Journal of Corporate Responsibility and Leadrship, 4 (1/2017), 79-91.

Ying, L., Xu, Ch., Jing, Z., Qingting, T., \& Jia, H. (2016). Development of The Attachment Affective Picture System. Social Behavior \& Personality: an International Journal, 44 (9), 1565-1574. 


\section{Appendix}

Table 4. Mann-Whitney test for differences in loyalty for employees trained in some way and those not trained at all

\begin{tabular}{|l|l|l|l|l|l|}
\hline & U Statistics & W Wilcoxon & Z & Asymptotic significance (two-tailed) & Glass rank coefficient \\
\hline Loyalty in Russia & 4106.00 & 4602.00 & -1.73 & 0.084 & - \\
\hline Calculative loyalty in Russia & 4465.50 & 4961.50 & -1.05 & 0.292 & - \\
\hline Affective commitment in Russia & $\mathbf{3 9 4 1 . 0 0}$ & $\mathbf{4 4 3 7 . 0 0}$ & $\mathbf{- 2 . 0 5}$ & $\mathbf{0 . 0 4 0}$ & $\mathbf{0 . 2 2}$ \\
\hline Loyalty in Poland & $\mathbf{1 0 8 7 4 6 . 0 0}$ & $\mathbf{1 1 8 6 1 6 . 0 0}$ & $\mathbf{- 2 . 3 6}$ & $\mathbf{0 . 0 1 8}$ & $\mathbf{0 . 1 2}$ \\
\hline Calculative loyalty in Poland & 120856.50 & 1677586.50 & -0.28 & 0.777 & - \\
\hline Affective commitment in Poland & $\mathbf{1 0 2 2 8 7 . 0 0}$ & $\mathbf{1 1 2 1 5 7 . 0 0}$ & $\mathbf{- 3 . 4 1}$ & $\mathbf{0 . 0 0 1}$ & $\mathbf{0 . 1 7}$ \\
\hline
\end{tabular}

Source: Author's own computations based on the survey data

Table 5. Mann-Whitney test for differences in loyalty for employees trained in open, non-bank specific training programs targeted at employees from different sectors and institutions and those not participating in this particular type of training

\begin{tabular}{|l|l|l|l|l|l|}
\hline & U Statistics & W Wilcoxon & Z & Asymptotic significance (two-tailed) & Glass rank coefficient \\
\hline Loyalty in Russia & 4070.50 & 4395.50 & -0.01 & 0.993 & - \\
\hline Calculative loyalty in Russia & 3922.50 & 4247.50 & -0.29 & 0.772 & - \\
\hline Affective commitment in Russia & 3796.00 & 57097.00 & -0.58 & 0.564 & - \\
\hline Loyalty in Poland & $\mathbf{1 9 7 7 5 0 . 0 0}$ & $\mathbf{1 4 6 8 9 6 5 . 0 0}$ & $\mathbf{- 4 . 5 3}$ & $\mathbf{0 . 0 0 0}$ & $\mathbf{0 . 1 7}$ \\
\hline Calculative loyalty in Poland & $\mathbf{2 1 1 0 2 2 . 5 0}$ & $\mathbf{1 4 8 0 6 4 3 . 5 0}$ & $\mathbf{- 3 . 0 0}$ & $\mathbf{0 . 0 0 3}$ & $\mathbf{0 . 1 1}$ \\
\hline Affective commitment in Poland & $\mathbf{2 0 7 8 4 7 . 5 0}$ & $\mathbf{1 4 7 9 0 6 2 . 5 0}$ & $\mathbf{- 3 . 3 7}$ & $\mathbf{0 . 0 0 1}$ & $\mathbf{0 . 1 2}$ \\
\hline
\end{tabular}

Source: Author's own computations based on the survey data

Table 6. Mann-Whitney test for differences in loyalty for employees trained in internal, bank-specific training programs and those not participating in this particular type of training

\begin{tabular}{|l|l|l|l|l|l|}
\hline & U Statistics & W Wilcoxon & Z & Asymptotic significance (two-tailed) & Glass rank coefficient \\
\hline Loyalty in Russia & 14951.00 & 32529.00 & -0.41 & 0.686 & - \\
\hline Calculative loyalty in Russia & 14949.50 & 32527.50 & -0.31 & 0.756 & - \\
\hline Affective commitment in Russia & 14428.00 & 32006.00 & -0.97 & 0.334 & - \\
\hline Loyalty in Poland & $\mathbf{3 9 1 4 4 3 . 5 0}$ & $\mathbf{6 8 9 0 4 9 . 5 0}$ & $\mathbf{- 3 . 4 7}$ & $\mathbf{0 . 0 0 1}$ & $\mathbf{0 . 0 9}$ \\
\hline Calculative loyalty in Poland & 416153.00 & 712988.00 & -1.31 & 0.190 & - \\
\hline Affective commitment in Poland & $\mathbf{3 8 8 0 2 0 . 0 0}$ & $\mathbf{6 8 5 6 2 6 . 0 0}$ & $\mathbf{- 3 . 7 8}$ & $\mathbf{0 . 0 0 0}$ & $\mathbf{0 . 1 0}$ \\
\hline
\end{tabular}

Source: Author's own computations based on the survey data 
Table 7. Mann-Whitney test for differences in loyalty for employees trained in On-The-Job Training initiatives and those not participating in this particular type of training

\begin{tabular}{|l|l|l|l|l|l|}
\hline & U Statistics & W Wilcoxon & Z & Asymptotic significance (two-tailed) & Glass rank coefficient \\
\hline Loyalty in Russia & 15392.50 & 30617.50 & -0.01 & 0.995 & - \\
\hline Calculative loyalty in Russia & 15190.50 & 30943.50 & -0.13 & 0.989 & - \\
\hline Affective commitment in Russia & 15283.50 & 30508.50 & -0.12 & 0.902 & - \\
\hline Loyalty in Poland & 430289.00 & 749889.00 & -0.51 & 0.610 & - \\
\hline Calculative loyalty in Poland & $\mathbf{4 0 7 7 6 3 . 5 0}$ & $\mathbf{7 2 7 3 6 3 . 5 0}$ & $\mathbf{- 2 . 4 3}$ & $\mathbf{0 . 0 1 5}$ & $\mathbf{0 . 0 7}$ \\
\hline Affective commitment in Poland & 422699.00 & 1019477.00 & -1.17 & 0.244 & - \\
\hline
\end{tabular}

Source: Author's own computations based on the survey data

Table 8. Mann-Whitney test for differences in loyalty for employees trained in e-learning courses and those not participating in this

\begin{tabular}{|l|l|l|l|l|l|}
\hline & U Statistics & W Wilcoxon & Z & Asymptotic significance (two-tailed) & Glass rank coefficient \\
\hline Loyalty in Russia & $\mathbf{2 9 2 6 . 0 0}$ & $\mathbf{3 3 6 1 . 0 0}$ & $\mathbf{- 2 . 3 6}$ & $\mathbf{0 . 0 1 8}$ & $\mathbf{0 . 2 7}$ \\
\hline Calculative loyalty in Russia & 3193.50 & 3628.50 & -1.75 & 0.08 & - \\
\hline Affective commitment in Russia & $\mathbf{2 9 0 2 . 0 0}$ & $\mathbf{3 3 3 7 . 0 0}$ & $\mathbf{- 2 . 4 4}$ & $\mathbf{0 . 0 1 5}$ & $\mathbf{0 . 2 7}$ \\
\hline Loyalty in Poland & 132981.50 & 156417.50 & -1.18 & 0.238 & - \\
\hline Calculative loyalty in Poland & 135396.50 & 975852.50 & -0.67 & 0.501 & - \\
\hline Affective commitment in Poland & $\mathbf{1 2 4 8 7 9 . 5 0}$ & $\mathbf{1 4 8 3 1 5 . 5 0}$ & $\mathbf{- 2 . 5 6}$ & $\mathbf{0 . 0 1}$ & $\mathbf{0 . 1 1}$ \\
\hline
\end{tabular}

Source: Author's own computations based on the survey data

\section{Acknowledgements}

This research was supported by the project, which has received funding from the Implemented with support of the Russian Foundation for Basic Research (project 19-29-07131 "Modelling and measurement of human capital and its forms in the context of economy digitalization: resources, flows, institutions"). 


\section{ENTREPRENEURSHIP AND SUSTAINABILITY ISSUES}

ISSN 2345-0282 (online) http://jssidoi.org/jesi/ 2020 Volume 8 Number 1 (September) http://doi.org/10.9770/jesi.2020.8.1(71)

Jerzy KAŹMIERCZYK is the Adjunkt at the Poznan University of Economics and Business in the Department of Education and Personnel Development in Poznan, Poland. He is the Secretary and a Member of the Board of Research Council of the Polish Economic Society, a Member of the Presidium and Board of the Polish Economic Society Zielona Gora, Poland, and a Member of the Regional Labour Market Board by Lubuskie Marshal's Office, Poland. Research interests: labour market, education, trainings, loyalty, banks.

ORCID: 0000-0002-5976-0210

Gulnara Fatykhovna ROMASHKINA is the Doctor of Science and Professor at the Department of Mathematical Methods, Information Technologies and Management Systems in the Economy, at the Tyumen State University, Russia. Research interests: labour market, human capital, mathematical methods

ORCID: 0000-0002-7764-5566

Przemyslaw MACHOLAK is an alumnus of the Huntsman Program in International Studies and Business at the University of Pennsylvania, USA. Member of the Polish Economic Society in Zielona Gora, Graduated Magna Cum Laude, Wharton Research Scholar and Perry World House Student Fellow. He is currently working for a global management consulting firm. The views in this article are purely my own. In no way is this article related to, informed by or endorsed by my employer. Research interests: education, human capital, labour market, international business

ORCID: 0000-0003-4230-5446

Make your research more visible, join the Twitter account of ENTREPRENEURSHIP AND SUSTAINABILITY ISSUES: @Entrepr69728810

Copyright (C) 2020 by author(s) and VsI Entrepreneurship and Sustainability Center This work is licensed under the Creative Commons Attribution International License (CC BY). http://creativecommons.org/licenses/by/4.0/

(c) (i) Open Access 